\title{
Kampala Convention and Accountability in the Management of Internally Displaced Persons (IDPs) in Nigeria
}

\author{
Atim, Grace \\ Institute for Peace \& Conflict Resolution \\ Ministry of Foreign Affairs \\ Abuja \\ Atsiya-Pius, Godiya Ph.D \\ Department of Political Science \\ Nasarawa State University Keffi
}

\begin{abstract}
In an era of protracted violent conflicts of different types, trends and dimensions, there is bound to be increased displacements, dislocations, disruptions and vulnerabilities. The displacement of persons during violent conflict increases vulnerability by exacerbating existing and creating new conditions that encourage further sufferings and trauma, especially of women and children who naturally bear its greater brunt. This study interrogates the applicability of the African Union Convention for the Protection and Assistance of Internally Displaced Persons in Africa (also known as the Kampala Convention) and other human rights instruments that provides for the protection and assistance of internally displaced persons. It is against this backdrop that the paper adopts the theory of Forced Migration to situate its argument in view of rising situation of natural disasters and violent conflicts that currently engulf Nigeria leading to massive displacements. The paper advocates for the domestication and implementation of the Kampala Convention that Nigeria had signed in the management of humanitarian crisis, building durable solution and sustainable peace.
\end{abstract}

Keywords: Displacement, Women, Internally Displaced Persons, Kampala Convention

\section{Introduction}

Intra-state and intra-regional armed conflicts have continued to result in substantial internally displacements in Africa as examplied in the Biafra War in Nigeria (1967-1970); the liberation struggle in Guinea-Bissau (1963-1973); the Casamance Independence Movement in Senegal (1980s till date); the Mauritanian conflict of 1989; the terrible conflict which tore apart the River Mano countries of Sierra Leone and Liberia between 1999 and 2000; the Nigeria-Cameroun Bakassi Peninsula conflict; the post electoral crisis in Ivory Coast (2010-2011); the political crisis in Mali; as well as the on-going Boko Haram insurgency in Nigeria, Cameroon, Chad and Niger. Similarly, natural disasters have exacerbated the incidents of massive displacements within nation-states (Ewaka, 2016).

In the last decade, Nigeria has witnessed millions of people that are internally displaced as demonstrated in a Report titled: Global Overview of 2014 People Internally Displaced by Conflict and Violence compiled by Internal Displacement Monitoring Center (IDMC) and the Norwegian Refugee Council (NRC). Equally, Campbell (2016) states that:

The number of internally displaced persons in Nigeria is approximately a third of the IDPs in Africa and 10 per cent of IDPs in the world. The report ranked Nigeria $3^{\text {rd }}$ with 3.3 million displaced persons, behind Syria and Columbia which have 6.5 million IDPs respectively.

The key factors that have contributed significantly to the high level of forced movements of population (displacement) in Nigeria include the Boko Harm insurgency, violence between farmers and nomadic herders, land disputes, resourcebased conflicts, ethno-religious conflicts, election-related violence, banditry and communal disputes. At the center of victomhood are women and children who continued to bear the brunt of the intractable violent conflicts.

Women account for around half of the world's 33.2 million internally displaced persons (IDPs) (Brookings, 2014). In addition to many general human rights violations faced by all IDPs, women are often at greater risk than other affected populations (Brookings, 2014). Women face lost of livelihoods and key documentation needed for daily life. They tend to have less access to assistance, protection and struggle for access to adequate education, healthcare, training and livelihoods. They are more susceptible to sexual and gender-based violence (SGBV) and are likely to face difficulties in exercising their rights to housing, health, land, and property. 
Additionally, they are excluded from decision-making processes on critical issues that affect their wellbeing and security. These human rights violations are compounded by conflict, which exacerbates pre-crisis discrimination patterns. In a bid to curb displacement crisis in Nigeria and its neighboring states, majority of African states have signed the African Union Convention for the Protection and assistance of Internally Displaced Persons also known as the Kampala Convention of 2009. The Convention reflects the international guidance provided in the United Nations Guiding Principles on Internal Displacement, which sets out the international norm on IDPs (Ekpa \& Dahlan, 2016). The main objective of the Kampala Convention is to "promote and strengthen regional and national measures to prevent or mitigate, prohibit and eliminate root causes of internal displacement as well as provide for durable solutions" (as cited in Kampala Convention, 2009:4).

It is against this problem that this paper seeks to interrogate the Kampala Convention and other legal instruments that have provisions for the protection and assistance of internally displaced women and children. The paper will advocate for the domestication and mechanism put in place for implementation of the convention which Nigeria is signatory.

\section{IDPs Figure Analysis in Nigeria (2012 - 2019)}

The humanitarian situation in Nigeria deteriorated significantly between the periods 2012-2018 due to natural disasters, communal clashes, political violence, electoral violence, Farmer/Herder conflicts in the Middle-Belt region, Boko Haram terrorism and counterterrorism measures. The Internal Displacement Monitoring Centre (IDMC) reports that in 1982, only 1.2 million people were IDPs in 11 countries. This figure has risen over the years to 28.8 million by the end of 2012. Out of this estimate about 4 million are displaced in Nigeria with about 1.5 million displaced as a result of the Boko Haram insurgency in the north east and environs.

According to the United Nations High Commissioner for Refugees (UNHCR), the number of IDPs doubled in the span of three years from some 868,000 people identified at the end of 2014 to 1.7million by June 2017 in Nigeria. In 2015, the United Nations Children Fund (UNICEF) reported that the number of IDPs in eight states of Borno, Yobe, Adamawa, Nasarawa, Taraba, Bauchi, Gombe and Federal Capital Territory (FCT) is 2,049,810. These IDPs occupied government camps, public schools, and places of worship.

Today, Nigeria is said to rank as the third country in Africa with the highest number of internally displaced populations. The most recent data released in October, 2018 by the Displacement Tracking Matrix Report from International Organisation for Migration (IOM) states that figures of IDPs in Nigeria have risen from 1,706,818 to $2,026,602$.

The establishment of National Emergency Management Agency (NEMA) by the Federal government was a bid to address and respond swiftly to emergency situations in the country. The Nigerian government has made several unending efforts to addressing the plights of IDPs by putting in place different strategies to address the IDPs crisis. Paradoxically, the problems of hunger, overcrowding, poor sanitation, sexual and gender-based violence, joblessness and insecurity continues to persist among IDPs across the country (Itumo \& Nwefuru, 2016). Moreover, there are IDP Camps set up in over 200 local government areas of Nigeria. These Camps are provided in collaboration with the United Nations, other international organizations, and non-profit organizations (UNHCR, 2014). The Nigerian government also established programs to respond to the humanitarian crisis such as the North-East Development Commission (NEDC) that replaced the Presidential Committee on North East Initiative (PCNI). These efforts seem to have yielded little impact as crisis of internally displaced persons persists in the country.

Despite all these efforts by the government to alleviate the sufferings of IDPs, there seems to be obvious inadequacy of programmes and effective delivery of the strategies of government in tackling the challenges of IDPs in Nigeria. Thus, the needs to come up with better or improved strategies that will help the existing effort of governments (Federal, states and local) to tackle the problem of the internally displaced persons.

\section{Problem of the Study}

Since the escalation of the Boko Haram insurgency into a deadly conflict in 2009, the group have caused an enormous threat to human security in Nigeria. The phenomenon has also forced almost 2 and half million people to flee; as a result, Nigeria became the highest in number of Internally Displaced Persons (IDPs) in sub-Sahara Africa (Norwegian Refugee Council, 2017). The Displacement Tracking Matrix (DTM) revealed that women and children formed $79 \%$ of the IDPs population, and children under 5 years formed 28\%. In the same vein, the United Nations Office for the Coordination of Humanitarian Affairs (UNOCHA), further revealed that IDPs in North-Central Nigeria are in desperate need of live-saving assistance such as food and nutrition, health care, shelter and non-food items, portable water and improved sanitation and hygiene condition. The condition of the IDPs has been reluctantly handled. Also, the IDPs suffer from some protection issues such as Child protection and Gender-based violence (CGBV) among others. 
Often, without the protection of family and communities they had before displacement, internally displaced women are vulnerable to rape, domestic violence, force prostitution, trafficking and many other abuses in violent situations. Women who have lost their husbands to conflict, also face additional challenges and responsibilities such as heads of households, and often have to rely on basic survival skills (Brookings, 2014). The prospect of IDPs to return to their original community is another worrisome issue adding to the plight of these displaced people (UNOCHA, 2018).

However, despite the humanitarian crisis and the suffering of the victims, there is no clear institutional and policy framework or legislation that directly and squarely address the plight of the IDPs. Although the cluster framework of humanitarian responses exit at the international level, but this absence of structures at the national level has retarded the philanthropic efforts of the international actors including the United Nations Agencies.

\section{Theoretical Framework}

This paper therefore adopted theory of Forced Migration to anchor the argument. The Forced Migration theory can be traced to the establishment of the League of Nations and its High Commissioner for Refugees in 1921 as a reaction to the large scale displacement caused by the 1917 Russian Revolution, the oppression of the Jews by the Nazis in Germany, the dissolution of the League of Nations and the Second World War where over 30 million people were displaced. Thus, the United Nations Relief and Reconstruction Agency (UNRRA) was created in 1944 (Benz \& Hasenclever, 2009).

Forced migration theory entails the involuntary movement of people from their places of habitual residence as a result of events which are threatening to their lives or safety (Benz \& Hasenclever, 2009). Prior to the Cold War, trends in the number of people seeking political asylum from their countries were alarming not until the end of the Cold War that the trend took another perspective to include numbers of people seeking refuge in their own countries as a result of being displaced by one activity of the government or the other.

From the above it can be deduced that categories of person who are internally displaced include those displaced by armed conflict, armed groups, natural disasters, environmental disasters as well as developmental projects.

Forced migration increases fears of the inability of the government to control the state especially within the context of recent concerns about migration and security (Castles, 2003). The forced migration theory tries to explain the dramatic increase of involuntary movement of people in the post- Cold War era and describes the harsh conditions in which these persons strive for a living. The limitation of this theory is its inability to include the responsibility of the government as being obligatory in curbing the excesses of the forced migration either internally or externally. Nevertheless, in the context of this study, the theory of forced migration explains the involuntary movement of the people internally displaced and explains the vulnerabilities of these people within their countries.

\section{The United Nation's Guiding Principles on Internal Displacement}

A number of standard and guidelines relating to IDPs, especially women have been developed over the past twenty years, covering such issues as reproductive health, sexual and gender-based violence and other cross-cutting issues. The United Nation's Guiding Principles on Internal Displacement provides an overarching normative framework that applies international human rights and humanitarian law to IDPs. They were among the first international frameworks to outline specific rights relevant to women facing internal displacement, including:

- Non-discrimination and right of expectant mothers, mothers of young children, and female heads of household to protection and assistance that "takes into account their special needs".

- Protection from sexual and Gender-based Violence (SGBV) and other forms of violence and exploitation

- The right to access all necessary documents, education and training

- The need for internally displaced women to actively participate in decision-making at all stages of displacement.

However, there are still gaps in the implementation and domestication of these policies. It is the national governments that are responsible for protecting and assisting all IDPs, including IDP women. It is thus the responsibility of states to ensure that the particular needs of displaced women and children are recognized and address in national laws and policies. Sometimes, the governments are simply unaware of the particular needs of women; sometime they lack the capacity to implement programs that will ensure that IDPs women's concerns are taken seriously.

Displaced women need to be able to claim their rights and seek redress for violations, including challenging harmful practices such as exclusion from inheritance. Any reparations mechanisms, set out in the convention, will only work if the many barriers to women assessing their housing and lands rights are lifted. Establishing additional mechanism cannot replace a state's obligation to provide displaced women with effective remedies when their rights are denied by their families and communities. 


\section{African Union Convention for the Protection and Assistance of Internally Displaced Person in Africa (Kampala Convention, 2009)}

In a bid to curb the Internal Displacement crisis, Nigeria and other African states have signed the AU Convention, also known as the Kampala Convention for the protection and assistance of internally displaced persons in 2009 which was adopted on the foundation of the UN Guiding Principles. This was endorsed by West African states at the first Conference on Internal Displacement in Abuja in April, 2006. It entered into force in 2012, becoming the world's first legally binding regional instrument to protect the rights of those uprooted. When the convention was ratified, it required that states adopt laws and policies or amend their legislation in line with its provisions. The significance of the Convention is that the "the enforcement elevates the discourse on IDPs protection beyond humanitarian" interventions. Under Article 9, "Obligations of States Parties Relating to Protection and Assistance during Internal Displacement" State Parties shall in Section 2(1):

Take necessary measures to ensure that internally displaced persons who are citizens in their country of nationality can enjoy their civic rights and political rights, particularly public participation, the right to vote and be elected to public office.To date, 40 African states have signed the convention, and 25 have ratified it. Nigeria ratified the convention in April, 2012 but is yet to domesticate it (Mohammed, 2017). The main objective of the Kampala Convention is to "promote and strengthen regional and national measures to prevent or mitigate, prohibit and eliminate root causes of internal displacement as well as provide for durable solutions" (as cited in Kampala Convention, 2009:4).

However, the Kampala Convention contains the following provisions incorporating a gendered approach to protection and assistance, with most pertaining to the specific obligations of state parties (Brookings, 2014):

- Sexual and Gender-based Violence (SGBV): State parties are obliged to "protect the rights of internally displaced persons regardless of the causes of displacement by refraining from, and preventing," various acts, including: :Sexual and gender based violence in all its forms, notably rape, enforced prostitution, sexual exploitation and harmful practices, slavery, recruitment of children and their use in hostilities, forced labour and human trafficking and smuggling" (Article 9.1.d);

- General Protection and Assistance: States parties shall "provide special protection for and assistance to internally displaced persons with special needs, including separated and unaccomplished children, female heads of households, expectant mothers, mothers with young children, the elderly and persons with disabilities or with communicable diseases"; (Article 9.2.c).

- Reproductive and Sexual Health: States parties shall "Take special measures to protect and provide for the reproductive and sexual health of internally displaced women as well as appropriate psycho-social support for victims of sexual and other related abuses" (Article 9.2.d).

- Registration and Personal documentation: "Women and men as well as separated and unaccompained children shall have equal rights to obtain such necessary identity documents and shall have the right to have such documents issued in their own names" (Article 13).

The Kampala Convention made provision for women to be protected from SGBV. However, the bane has been the non domestication of the convention.

\section{National Emergency Management Agency (NEMA)}

The National Emergency Management Agency (NEMA) was established via Act 12, as amended by Act 50 of 1999, to manage disasters in Nigeria. NEMA's mandate is to address disaster-related issues, coordinate responses to all emergencies, and provide relief through the establishment of concrete structures and measures. A chairman, who is supported by several directors at the top management level, heads the agency. NEMA's activities are guided by a number of plans and frameworks including: The National Contingency Plan, Search, \& Rescue and Epidemic Evacuation Plan, National Disaster Management Framework (NDMF), Emergency Response Standard Operating Procedures. The NDMF is the current framework used to manage internal displacement due to disaster or conflict. NEMA operates a 24/7 situation room that monitors and provides relevant information in the case of disasters. When a disaster happens, the Zonal Coordinator or State Emergency Management Agencies (SEMA) provides the required information to the headquarters. Required assistance is then provided, depending on the situation, including humanitarian assistance and rebuilding.

NEMA and SEMAs have to date been leading management and humanitarian support activities for internally displaced persons as well as search and rescue missions in disaster situations in Nigeria, and have provided some assistance to displaced persons across the borders of neighboring countries in the northeast.

The establishment of National Emergency Management Agency (NEMA) by the federal government of Nigeria was a bid to address and respond swiftly to emergency situations in the country. 
The Nigerian government has made several unending efforts to addressing the plights of IDPs by putting in place different strategies to address the IDP crisis, paradoxically, the problems of hunger, overcrowding, poor sanitation, Gender and sexual based violence, joblessness and insecurity continues to persist among internally displaced persons across the country (Itumo \& Nwefuru, 2016). Moreover, there are IDP camps set up in over 200 local government areas of Nigeria. These camps are provided in collaboration with the United Nations, other international organizations, and non-profit organizations (UNHCR, 2014). The Nigerian government also established programs to help alleviate the IDP crisis in the region such as the North-East Development Commission (NEDC), Presidential Committee on North East Initiative (PCNI). These efforts seem to have yielded little or no impact as crisis of internally displaced persons persists in the country.

Despite all these efforts of the government to alleviate the internal displacement crisis, there seems to be obvious inadequacy of programmes and effective delivery of the strategies of government in tackling the challenges of IDPs in Nigeria.

\section{The Constitution of the Federal Republic of Nigeria, 1999, as amended}

The Nigerian Constitution came into force on May 29, 1999. It provides the framework for the administration of both the Federal Government of Nigeria as well as the states, and its provisions have binding force on all authorities and persons throughout the country. The constitution states the obligation of the state to ensure the promotion of the security and welfare of all the people; and outlines citizens' rights as: the rights to life, human dignity, personal liberty, privacy, and family life, a fair hearing, freedoms of religion, expression, assembly, association, movement, from nondiscrimination, and to acquire and own immovable property.

\section{The National Commission for Refugees, Migrants, and Internally Displaced Persons (NCFRMI)}

Established by Decree 52 of 1989 now Cap. N21, Laws of the Federation of Nigeria, 2004 (NCFRMI Act), the Commission for Refugees, Migrants and Internally Displaced Persons is the coordinating agency of all migrationrelated issues in Nigeria. Apart from its operation role in providing protection and assistance to refugees and internally displaced persons, it also provides the lead for conducting activities relating to the assisted voluntary return and reintegration (AVRR) for Nigerians who may be in irregular situations abroad and who may have indicated their interest to return home.

The Commission's mandate was expanded on by the federal government through an executive order to cover issues relating to internally displaced persons (IDPs) and the coordination of migration and development in 2002 and 2009, respectively. This expansion has been contentious, as the bill to repeal the NCFR Act of 2000 to extend its mandate to IDPs, stateless persons, and migrants was never passed and therefore is yet to acquire the legal approval required. The Commission has, however, since then changed its name and is working towards the appropriate legislative amendment. Despite efforts to coordinate some activities, there has been some tension regarding the overlapping of mandates between NCFRMI and NEMA over the past few years. Coordination efforts have, however, improved recently with the change in leadership.

\section{National Policy on Internal Displacement in Nigeria}

In 2003, the National Commission for Refugees pushed for the development of a national policy on internal displacement. A presidential committee was set up to draft a national policy that would enhance the prevention of internal displacement, and propose best practices for the management of internally displaced persons, including the protection of their human rights and the need to mitigate their suffering once displacement has occurred. The draft Policy outlines roles and responsibilities for the federal, state, and local governments, as well as other stakeholders in the civil society, and national and international actors. In addition, it educates people about their rights and obligations before, during, and after displacement. The policy, which has been revised twice-in 2009 and 2012-has remained a "draft" policy, as it is yet to be adopted by the legislature. The main challenge here seems to also be linked to the process of domestication of the Kampala Convention, with the overlap of mandates and a lack of clear leadership direction on which agency owns the process. The issue is currently being revisited by the new leadership of the NCFRMI and the parliamentary committee on IDPs within a technical working group being set up by the NCFRMI.

\section{Interrogating the Legal Documents for the Protection and Assistance of Internally Displaced Women and Children in Nigeria}

Essentially, the government is central to the IDPs management, protection and provision of social, psychological and other material resources in any country. Unfortunately, the majority of countries in Africa faced with the challenges of IDPs do not show much commitment, sometimes for the want of the needed resources to achieve the basic goals as enshrined in the United Nations charter and the Kampala convention on the protection of the IDPs. 
Many of the countries facing the challenges of displacement of their own people as a result of the insurgency, war or communal conflicts, reveals the manifest consequences of social complex pluralism and relations and there is great difficulty managing such social complexities motivated by extraneous factors that are largely internally construed (Ladan, 2011).

In most circumstances, since no society is entirely free from the consequences of IDPs of any kind, whether human or naturally caused, countries tend to render humanitarian in different forms - logistics, relief, financial assistance, and moral support among others - to aid the challenges of the lack of access to water, sanitation, dignity, education and basic education among others.

The situation in Nigeria has received huge contributions from the government, wealthy individuals, international community and donor agencies who donated generously towards the resettlement of the IDPs, but the condition of the IDPs did not improve dramatically (Odufowokan, 2016).

In fact, much has not been done by the Nigerian government, such that there is noticeable inadequacy relief coming from the government, which means many of the IDPs requiring support could not get it. In this context, there is much reliance on the non-state actors for the purpose of financing and aiding the precarious conditions of the IDPs in the North-central. The fund donated by the non-governmental organizations and individuals towards alleviating the plight of the troubled people has been enormous.

Odufowokan (2016) reported that Aliko Dangote and other individuals donated 6.5 million Naira; the World Bank donated the sum of 800 million US dollars, the United Nations Development Programme (UNDP) donated 248 million US dollars for the rebuilding of the Northeast, out of which 24 million US dollars has been released. United States donated 200 million dollars; Saudi Arabia donated 750 million Naira, and the Australian government donated 9 million Naira respectively. Beside financial supports Nigeria government received to cater for the problems of the IDPs, there has been also material support given either directly to the IDPs or through the government.

The Nigeria-US Embassy on the 30 June 2016, made a press released revealing its support offered in respect of the IDPs in the Northeast through the United State Agency for International Development to the governments of affected people in Nigeria. Many people were expected to benefit from the gestures offered by USAID.

The assistance offered by international agencies, local and international donor groups and organizations, individuals and the government across the world to internally displaced persons in Nigeria is not only limited to the USAID. United Nations International Children Fund has also been assisting greatly in the Northeast Nigeria. The assistance by the UNICEF has been through the provision of finances to tackle challenges such as poor nutritional condition, health, WASH, child protection, education and sector coordination for the betterment of the IDPs particularly children conditions.

Despite Nigeria being a signatory to the Kampala Convention and other international instruments, this has not been adequately reflected in national policy and strategies because most of these policies and strategies have either not been adopted into national legislation and/ or suffer from poor implementation. In the absence of a policy framework on internal displacement in Nigeria, the response to the plight of IDPs has remained largely fragmented and uncoordinated; and the response to the root causes of internal displacement has been very poor and ineffective (Mohammed, 2017).

The lack of a clear policy or legal framework has also created tense relationships between government agencies with a weak system of accountability, particularly at the states level. There has been allegations of corruption by the authorities operating camps and those disbursing aid. The weak coordination between the donor community, governmental agencies, and the IDPs themselves has also led to support being inconsistent with ad hoc interventions. In addition, the approach towards addressing displacement so far appears to be heavily focused on short-term humanitarian aid and less on development-oriented, longer-term solutions, which could have serious implications for stability and security. This is of particular concern for the current situation in Nigeria, as the majority of displacement in the country is caused by conflict, mostly violent, which has socio-political and socio-economic implications. Displaced populations are, first of all, highly vulnerable, but can also post a potential threat to the host communities: both the host population and the environment (Mohammed, 2017).

\section{Conclusion}

The findings above reflect that there are inadequate provisions for policy frameworks and relevant institutional arrangements to manage IDPs in Nigeria. However, in reality, the policies remain mostly on paper, as the policy frameworks specific to IDPs have not been domesticated and are therefore not legally binding. Efforts to manage IDPs therefore remain ad- hoc, superficial, and with a focus on relief as opposed to addressing deeper issues, such as assistance and protection rights of the displaced. 
In addition, with the lack of clear mandates, which has led to overlaps, and the waste of much-needed resources, weak coordination, and synergy between the relevant institutions and bodies-specifically NEMA and NCFRMI- it is difficult to determine or address real issues related to the protection of IDPs. The entire process of domestication has been hindered by the conflicting mandates and the lack of proper coordination mechanisms.

While the process of domestication of the Kampala Convention is still ongoing, there is currently a private member bill in parliament, and the executive is working towards sending in a bill as well. However, this will play out eventually depending on stakeholder involvement at all stages including a public hearing-the NCRFMI is also in the process of finalizing modalities to hold a meeting of the Technical Working Group (TWG), which is the first step towards validating and sending the draft policy to Federal Executive Council for adoption and also addressing the issues of coordination, policy, and mandates.

\section{Recommendations}

During the course of this study, it has become obvious that Nigeria faces numerous challenges in its attempt to manage the humanitarian crisis brought about by internal displacement and especially so by the impact of the Boko Haram insurgency. In view of this, the study provides the following recommendations as options in handling the recurrent internal displacement crisis in Nigeria;

i. National government should, in accordance with the United Nations Guiding Principles on Internal Displacement and other international obligations, ensures that national laws and policies are adopted and that they provide comprehensive protection for displaced woman;

ii. The National government should also initiate gender sensitive budgeting processes that ensures that programs to address the needs to women receive adequate resources;

iii. In the occasion that internal displacement does happen, it is pivotal for the humanitarian network at all levels in Nigeria to be in a situation to react better to both quick and long term needs of IDPs, especially women. In this way, NEMA as the central agency coordinating the efforts of other bodies and institutions managing IDPs in the country should be restructured to bridge all strategic, logistical and institutional shortcomings which decrease its ability to function in the role determine for it by its enabling act;

iv. One detectable issue of NEMA is access to fund. Depending on funds from the government which is frequently not accessible limits the capacity of the agency to address the issues of IDPs in a convenient way. It is, therefore, recommended that a special account financed specifically from the national yearly budget be made and be made accessible to NEMA from which it may draw funds to meet the expedient needs of IDPs in a well-timed manner.

v. The government should make efforts to address certain causative agents of internal displacement like boundary disputes, indigene/settler dichotomy and farmer/herdsmen clashes. This may be accomplished via the creation of special courts to address such issues which may provide the seeds of tension with the capacity to erupt in violent conflict setting off a wave of internal displacement.

vi. The government should incorporate gender-sensitive approaches to policy and program implementation on IDP issues and increase the capacity of officials, especially at local levels, to implement these approaches;

vii. Government must train and retrain NEMA and SEMAs staff. This can be achieved through capacity building seminars and workshops with collaboration with foreign organizations like the United Nations so as to furnish its workers with requisite technical know-how and specialized training for improved emergency preparedness and response to conflict- induced displacement at both the national and state level.

viii. The state of IDPs in Nigeria is generally marked by destitution owing largely to corruption of a few unscrupulous government officials. Therefore, officials found guilty of corruption should be made to suffer the full legal consequences of their illegal action. This is so because in the bid to cover up their activities, national and international humanitarian organizations are denied direct, full and unconditional access to IDPs in their places of refuge thereby prolonging their suffering.

ix. There should be conscious effort by the government build upon existing peace and reconciliation efforts by promoting awareness campaigns, through the mediums of local radio and other media, and in community gatherings, that focus on commonalities rather than differences between ethnic and religious groups. The government should conduct awareness-raising programs to enhance the relationship between displaced persons and host communities, especially other women in those communities. This initiative will be advanced in no small way if the reconciliation process ensures that instigators and perpetrators of the violence are identified, including members of the security forces, and made to face justice.

$\mathrm{x}$. Concerted efforts should be made by institutions involved to fast track encourage and quicken the ratification of the National IDP Policy current anticipating endorsement since 2012. It has been established that without a central 
agency managing and coordinating efforts aimed at internal displacement, ad-hoc measures will further exacerbate and worsen the condition of IDPs in the country.

xi. The study finally calls on political leaders to exhibit the needed political will required to implement policies and programs targeted at eradicating or dousing the causes of internal displacement. This is expedient in the face of frequent and elongated incidences of forced displacement as it remains antithetical to development.

\section{References}

Brookings Institution (2014), Improving the Protection of Internally Displaced Women: Assessment of Progress and challenges, Washington, D.C,www.brookings.edu

Campbell, J.(2016). 'Internal Displaced Continue to Grow in 2016' Council on Foreign Relations https://cfr.org

IOM (2018) Displacement Tracking Matrix, International Organization for Migration.

Ekpa, S. \& Dahlan, N.H.M. (2016). Legal Issues and Prospects in the Protection and Assistance of Internally Displaced Persons (IDPs) in Nigeria. Journal of Law, Policy and Globalization, 49, 108-116

International Displacement Monitoring Centre (2013). Nigeria: Increasing violence countries to cause internal displacement. A profile of the Internal Displacement Situation (IDMC) Norwegian Refugee Council.

International Displacement Monitoring Centre (IDMC) 2016, - Nigeria IDP Figures Analysis, http://www.internaldispacement.org/sub-saharan-africa/nigeria/figures-analysis Retrieved 4th March 2018.

Itumo, A. \& Nwefuru, N.H. (2016). Nigerian State and Responses to Plights of Persons

Internally Displaced by Boko Haram Insurgents: Implications for Socio-Economic and Political Development. Research on Humanities and Social Sciences, 6(15) 24-38

Kampala Convention (2009).s African Union Convention for the Protection and Assistance of Internally Displaced Persons in Africa.

Retrieved from http://www.eods.eu/library/AU_KAMPALA\%20CONVENTION_2009_EN.pdf.

Kampala Convention (2009). Article 9, Section 2 0, African Union Convention for Protection and Assistance for Internally Displaced Persons in Africa. Addis Ababa. p.11.

Ladan M.T. (2011). Overview of International and Regional Frameworks on International Displacement: A Case Study of Nigeria. A Paper Presented at a 2-day Multi-Stakeholders Conference on International Displacement in Nigeria. Organized by the Civil Society Legislative Advocacy Centre, Abuja in Collaboration with IDMC and the Norwegian Refugee Council, Geneva. Held on $21^{\text {st }}$-23rd November, 2011. at Bolton White Hotels Abuja, Nigeria.

Mohammed, F.K. (2017). Causes and Consequences of internal displacement in Nigeria and related Governance Challenges; Berlin: working paper FG 8

National Policy on Internally Displaced Persons (IDPs) in Nigeria. Federal Republic of Nigeria 2012.

National Emergency Management Agency (NEMA), (2015). http://nema.gov.ng/internally-displaced-persons-innigeria-rise-to-2-1-million/

http://www.informationng.com/2017/07/finally-defense-headquarters-explain-bombed-idp-camp-rann.html

Odusanya, O.O. (2016). The Health of Internally Displaced Persons. Nigerian Postgraduate Medical Journal, 23(4), 159- 160. DOI. 10.4103/1117-1936.196241.

UNHCR (2014). United Nations High Commissioner for Refugee programme for internally displaced people in Nigeria.

UNICEF(2015). in Nigeria Civil Society Situation Room Eections Fact Sheet 